\title{
Licensing Biotech Intellectual Property in University-Industry Partnerships
}

\author{
Vladimir Drozdoff ${ }^{1}$ and Daryl Fairbairn ${ }^{2}$ \\ ${ }^{1}$ Business Development and Technology Transfer, Cold Spring Harbor Laboratory, Cold Spring Harbor, \\ New York 11721 \\ ${ }^{2}$ Clifford Chance US LLP, New York, New York 10019 \\ Correspondence: drozdoff@cshl.edu
}

Appropriate negotiation and drafting of license agreements are critical to successfully establishing and managing the expansive and complex relationships that are becoming more common between industry and universities. More often than not, the resulting licensing agreements become quite lengthy and complex, and the key principles become difficult to discern among all the details. This summary provides a short, nonexhaustive introduction to some of the essential components of these licenses with the intent of providing the nonlicensing professional a better appreciation of some of the key commercial and legal terms from both an academic and company perspective, keeping in mind some of the considerations that particularly apply to biotechnology deals.

\begin{abstract}
In 1980, the Bayh-Dole Act ushered in a new era for federally funded universities and other nonprofit institutions by allowing those institutions to own inventions arising from federally sponsored research. Although the merits of the act have been widely debated (Boettinger and Bennett 2006; Rai and Sampat 2012; Schacht 2012), it is generally regarded that the act has broadly encouraged commercialization of university-developed technology. This impact has been particularly felt in the field of biotechnology, whose rapid growth coincided with implementation of the act and the rise in licensing activity among academic institutions. With the expansion of technology transfer offices among academic institutions, by 2000 , about a dozen or so of the larger institutions were ranked among the top 40 recipients of biotechnology patents
\end{abstract}

in the United States (Edwards et al. 2003). A number of these patents have played fundamental roles in the commercialization of biotechnology, including Stanford University's Cohen-Boyer patents to recombinant DNA, which were licensed to over 450 companies. At the time they expired in 1997, these patents had generated more than $\$ 250$ million in licensing revenue (Feldman et al. 2007).

Today, revenue from commercialization of technology represents an increasingly important and substantial source of support for academic institutions in the United States, with combined revenues from licensing and industry-supported research in all fields reaching well over $\$ 6$ billion per year (AUTM 2012). Much of biotechnology-driven revenue in the past tended to be the product of a few blockbuster suc-

Editors: Salim Mamajiwalla and Rochelle Seide

Additional Perspectives on Intellectual Property in Molecular Medicine available at www.perspectivesinmedicine.org

Copyright (C) 2015 Cold Spring Harbor Laboratory Press; all rights reserved; doi: 10.1101/cshperspect.a021014

Cite this article as Cold Spring Harb Perspect Med 2015;5:a021014 
cesses, with a large proportion of revenue attributed to a relatively small number of deals (Brody 2001). However, as the pharmaceutical industry looks increasingly to academic-industry alliances and partnering as a means for conducting foundational pipeline research that in the past was done in-house, that picture is gradually changing. In the past few years, a growing number of larger-scale and longer-term framework partnerships have been established between a number of large pharmaceutical companies and academic institutions. A significant number of these framework partnerships have involved multiyear collaboration and drugdiscovery deals providing several million dollars of research support for the academic partner (Schachter 2012).

\section{DEFINING THE BIOTECHNOLOGY LICENSE AGREEMENT}

At the time they are drafted and negotiated, biotechnology license agreements involving academic institutions only rarely provide a readily commercializable product or technology. Most often, license relationships are established around relatively early-stage technology, where the path to an ultimate commercial product is not entirely certain. As such, understanding the expectations of both parties becomes particularly important in framing the scope of the license and the rights the agreement confers to both parties.

\section{Technology versus IP}

In simple terms, a license is a contract between two parties, which allows use of rights or materials belonging to one party by the other party, usually in return for some payment or other benefit. Having legal rights to or ownership of those rights and materials is therefore necessary to grant a license.

In this context, it is important to recognize the distinction between technology and intellectual property (IP), both of which are basic parts of most biotechnology deals. Technology, in general, refers to tools, methods, and materials - that is, things that are necessary or can be used by a party to conduct research and develop products under the agreement. IP, on the other hand, refers to a legally protectable right, such as a government-issued patent right or an unregistered trade secret, which allows a party to prevent or block others from using what is covered by that right. Although often crucially important to a deal, not all technology can be or is protected as IP. For example, when unpatentable research methods and other know-how are freely shared between scientists, instead of being kept as trade secrets, they receive no IP protection. Biotechnology license agreements are therefore often hybrid structures, which combine a research and development (R\&D) agreement component that provides for use and transfer of technology such as know-how and materials with a license agreement component that governs rights to existing and future developed IP.

\section{Purpose of the License Agreement}

A license agreement can be viewed as serving three primary purposes: (1) defining the scope of rights being transferred between the parties, (2) defining the compensation for those rights, and (3) putting in place a structure for managing the risks that each party takes on in carrying out the agreement. To effectively address each of these, it is critically important that the parties understand both the overall objective of the agreement and the more specific objectives each party has in entering into the agreement, especially in a combined R\&D and licensing deal.

Many of the same objectives repeatedly arise in deals between universities and companies. As an illustration, one can consider a drug discovery partnership. The overall objective of such a project may range from short-term research to validate potential biological targets to more extensive, long-term partnerships with the end goal of selecting a lead compound for clinical trials and eventual commercialization. Regardless of scope, each member in such a partnership will have its own more specific objectives. A license agreement can form an effective relationship management tool only if each of the parties' objectives are transparently negotiated 
and taken into account in structuring the terms and provisions of the agreement.

For the university, research and publication will always be primary objectives. Increasingly, however, universities also view such alliances as a means to directly participate in more effective translation of their research, for example, into new drugs. But in doing so and helping ensure that the public will benefit from their research, universities also remain accountable to their wider mission of advancing and disseminating knowledge. Part of that mission is to present and publish the results of the sponsored research they conduct. Another part is to safeguard the ability of their investigators and those at other publicly funded institutions to use the technology developed in such alliances.

The university, however, cannot overlook that fulfilling this mission depends on continued funding. Therefore, in sharing the longterm goal of successful commercialization, the university will also look to receive some fair share of revenue. An effective licensing agreement takes into account the total added value the university brings to the table. This includes not only the specific expertise of its investigators, but also the benefit the industry partner obtains from the investment in personnel and infrastructure that the university has made in developing its research capabilities.

For the pharma/biotech partner, a primary objective of almost any partnership is to contribute to its overall business strategy. As the strategic focus of the industry continues to shift away from internal early-stage $\mathrm{R} \& \mathrm{D}$, and key patents expire on successfully marketed drugs, biotech industry stakeholders are increasingly looking to university-based research for new leads to integrate into their drug discovery pipelines. Most such biotechnology deals are directed, at least initially, to the early stage of these pipelines.

\section{SCOPE OF THE LICENSE AGREEMENT}

Structuring the Agreement to Make Sense for the Deal

Deal structures can vary significantly, depending on the focus and scope of the collaboration.
Defining an appropriate scope of a license is often one of the more challenging starting points in negotiating a license agreement for an industry-university partnership, even with a well-defined project in mind. Often, the process becomes tied up in negotiations over rights to IP and technology that are unnecessary to carry out the collaboration, rather than on the rights each party actually needs to do so.

To determine an appropriate structure, the parties first need to identify the stakeholders on both sides who should be involved in the negotiation process. Those on the university side should understand how the drug discovery process is managed by their industry partner, who the key decision makers are, and what role their counterparts on the company side have at each stage in the process. For example, an exploratory project directed to identifying new oncology drug targets as compared to a drug discovery partnership to collaborate on a drug screen will likely engage different management teams and decision makers. As the potential scope of a collaboration changes during negotiations, and during the life of the relationship, different stakeholders, often with different concerns and priorities, may need to be brought into the process.

Ordinarily, objectives for obtaining a license fall into three categories: (1) to obtain access to technology necessary to develop and make a product or service (enabling technology); (2) to obtain legal freedom to make and sell the product or service (freedom to operate); and (3) to use as an offensive tool, for example, IP rights that the partner could use to exclude potential competitors from selling the same products or services (exclusivity in that market). One can draw a simple analogy to operating a food stand in a park. Here, enabling technology might equate to know-how and materials needed to make the food and run the equipment. Freedom to operate might equate to permits allowing one to run the business and serve food in the park. Finally, exclusivity might equate to being able to keep any other stands out of the park, or those in the park from serving food. Table 1 provides a general description of the range of potential relationships. 
V. Drozdoff and D. Fairbairn

Table 1. Agreement types

\begin{tabular}{|c|c|c|}
\hline & Purpose & Potential issues \\
\hline $\begin{array}{l}\text { Nondisclosure } \\
\text { agreement }\end{array}$ & $\begin{array}{l}\text { Nondisclosure agreement exchanged before the } \\
\text { licensing negotiation } \\
\text { Provides mechanism for discussing the subject } \\
\text { matter while preventing use of information } \\
\text { outside a narrowly permitted purpose }\end{array}$ & $\begin{array}{l}\text { Allocation of ownership of IP rights } \\
\text { arising from the discussion }\end{array}$ \\
\hline $\begin{array}{c}\text { Material transfer } \\
\text { agreement }\end{array}$ & $\begin{array}{l}\text { Transfer of biological materials (e.g., reagents, cell } \\
\text { lines, or vectors) for the purpose of research or } \\
\text { commercialization }\end{array}$ & $\begin{array}{l}\text { Requires recipient to assign or license } \\
\text { inventions back to the provider }\end{array}$ \\
\hline License agreement & $\begin{array}{l}\text { Grants rights to use patents and technology to } \\
\text { develop and commercialize new products }\end{array}$ & $\begin{array}{l}\text { Complex payment and IP rights } \\
\text { allocation mechanisms } \\
\text { Commercial risk lies with licensee }\end{array}$ \\
\hline $\begin{array}{l}\text { Collaboration } \\
\text { agreement }\end{array}$ & $\begin{array}{l}\text { Parties share resources, expertise, and risk of } \\
\text { success or failure depending on their relative } \\
\text { contributions } \\
\text { Use for access to new expertise, resources, or entry } \\
\text { into new markets } \\
\text { Takes advantage of synergies }\end{array}$ & $\begin{array}{l}\text { Shared commercial risk } \\
\text { Payment schemes and allocation of } \\
\text { obligations and liabilities are } \\
\text { highly varied } \\
\text { Importance of collaboration } \\
\text { management structures }\end{array}$ \\
\hline $\begin{array}{l}\text { Framework } \\
\text { partnership }\end{array}$ & $\begin{array}{l}\text { Company provides funding for multiple } \\
\text { projects } \\
\text { Long-term, exclusive relationships in a specific } \\
\text { field or with specific investigator groups } \\
\text { Becoming increasingly popular }\end{array}$ & $\begin{array}{l}\text { Takes longer to negotiate } \\
\text { Complex relationships }\end{array}$ \\
\hline
\end{tabular}

Many biotech deals begin well before the ultimate commercial product has been determined or development work has even begun. In such cases, there is often little certainty in what IP rights will ultimately be most important, and when negotiations begin, many details for the collaboration are unknown. Despite this, it is surprising how frequently license negotiations start with the parties attempting to negotiate from a detailed "standard" form agreement. Such an approach may be reasonable for simple transactions such as a material transfer agreement commonly used to exchange reagents between academic laboratories. But in more complex biotech deals, such an approach is rarely productive or efficient. In the end, attempting to fit the deal into a ready-made box only reduces the likelihood that the final agree- ment will in all respects accurately reflect the true understanding of each party.

\section{Term Sheets}

The ultimate success of complex biotech deals often hinges on the ability of the parties negotiating the deal to reach an effective understanding and agreement on the expectations, obligations, and risks each party will take on. Bypassing this step increases the chance for later misunderstanding and disputes, especially in more complex deals and when drafting a final license agreement comes under time pressure. Use of term sheets will almost always direct more effective and productive negotiations and is often the best approach to ensure that the parties reach a true consensus. 
Essentially, term sheets provide a summary of those issues that the parties consider as the most important aspects of the deal. Although its primary purpose is to act as a template for drafting a full, detailed agreement, a term sheetwhich, generally, is specified legally nonbinding-can provide a useful reference point to guide and focus the negotiation process from the beginning. Effective term sheets should be customized to reflect the unique requirements each deal presents. Ideally, the process of deciding what should go into a term sheet provides an opportunity to identify all the key provisions each party views as essential for their participation. If the parties are unable to agree on any deal, it is preferable to find out early in discussions rather than months later after drafting a complex agreement has consumed considerable financial and personnel resources. The more thought and discussion that go into preparing a term sheet, the lower the likelihood of any eventual misunderstanding. Some important provisions commonly negotiated in most biotech deals, and which would be included in a term sheet, are provided in Table 2.

\section{MANAGING IP RIGHTS}

In many technological areas, the owner of an IP right may not be best suited to commercially exploit the IP. For example, although well suited to encourage and enable primary research, academic institutions generally do not have the infrastructure, expertise, or financing required to shepherd a compound through clinical trials to commercialization. To help accomplish this and best commercialize its technology, the university may use a variety of strategies and licensing arrangements.

Licensed rights are commonly limited, for example, by field of use or territory. This consideration becomes particularly important when commercialization of a certain technology involves relationships with several partners. In the biotechnology sector, because patent rights can be subdivided in many different ways, it is common to grant a license for one particular field (e.g., treatment of pediatric oncology) but not another field (e.g., adult oncology or pediatric autoimmune disorders). As a result, the same patents may be licensed to different parties, each on an exclusive basis, but for different nonoverlapping fields of use. In such cases, care needs to be taken to avoid creating conflicting rights in multiple licensees. Conflicting rights might arise, for example, if multiple licensees have rights to control patent prosecution for the same patents or if they have other rights with respect to the licensed patents (such as a right to assignment of any licensed patents the academic licensor intends to abandon).

\section{Exclusive versus Nonexclusive Rights}

An exclusive license generally means that only the licensee may exercise the rights given in the agreement, even to the exclusion of the IP owner. Exclusivity generally includes the ability to enforce the licensed IP rights against others. For example, in a patent license, exclusivity will generally provide the licensee with the ability to sue third parties for patent infringement and also provide the licensee with the ability to sublicense all or part of its patent rights to others. Exclusive rights play a central role in the development and commercialization of molecular targets and drug candidates, because of the extensive cost and effort required to overcome the many risks involved in drug development.

On the other hand, a nonexclusive license in general only provides the licensee with permission to use the rights covered by a patent without giving the licensee any control over enforcement or licensing of such patent rights. Such a license therefore allows the IP owner to grant the same rights to several parties. These rights are most common for platform technologies with wide applications in different fields of use.

Parties, when negotiating a deal and drafting a good license agreement, should ensure that the scope of the licensed IP rights is clearly defined, including both nonexclusive and exclusive rights. It is often useful to assume that someone who was not involved in drafting or negotiating the agreement will need to understand, even years later, what is intended to be covered by the agreement. 
V. Drozdoff and D. Fairbairn

Table 2. Common provisions and terms included in biotech term sheets

\begin{tabular}{|c|c|c|}
\hline & Provisions and terms & Considerations \\
\hline \multirow[t]{3}{*}{ Project } & Scope & $\begin{array}{l}\text { Well-defined scope and responsibilities help to manage } \\
\text { expectations }\end{array}$ \\
\hline & People & $\begin{array}{l}\text { Use precise definitions to clarify what is "in" the deal and what } \\
\text { is "out" }\end{array}$ \\
\hline & Management & Active participation on each side helps ensure successful outcome \\
\hline \multirow[t]{2}{*}{ Technology } & Materials & $\begin{array}{l}\text { May need careful and precise definitions of technical terms to } \\
\text { avoid confusion }\end{array}$ \\
\hline & Know-how & \\
\hline \multirow[t]{7}{*}{ IP } & Existing IP & Ensure appropriate license scope to use existing IP \\
\hline & New (collaboration) IP & $\begin{array}{l}\text { Carefully consider allocation of new IP (who owns, who } \\
\text { enforces, any licenses?) }\end{array}$ \\
\hline & Ownership & \\
\hline & Licensed rights & \\
\hline & Options & \\
\hline & Reserved rights & \\
\hline & Exclusivity & \\
\hline \multirow[t]{3}{*}{ Publication } & Who can publish & $\begin{array}{l}\text { Balance basic mission of university to publish and disseminate } \\
\text { research against need of company to establish appropriate }\end{array}$ \\
\hline & Confidentiality & strategy to protect IP \\
\hline & Limitations and delay & \\
\hline \multirow[t]{4}{*}{ Payments } & Upfront fees & Make commercially reasonable to protect "bankability" \\
\hline & R\&D support & Use creative structures to share risk and bridge the gap between \\
\hline & Milestones & \\
\hline & Royalties & \\
\hline \multirow[t]{3}{*}{ Enforcement } & Who has rights? & $\begin{array}{l}\text { Define in detail to avoid conflicting default rules in different } \\
\text { jurisdictions }\end{array}$ \\
\hline & Obligation to cooperate & \\
\hline & $\begin{array}{l}\text { Sharing expenses and } \\
\text { awards }\end{array}$ & \\
\hline \multirow[t]{3}{*}{$\begin{array}{r}\text { Other common } \\
\text { provisions }\end{array}$} & Liability & $\begin{array}{l}\text { Define who has liability for third-party claims, for example, } \\
\text { patent infringement or product liability }\end{array}$ \\
\hline & Dispute resolution & Procedure for how to manage and resolve disputes \\
\hline & Termination & \\
\hline
\end{tabular}


Reserved Rights under the License: Research and Publication Rights

When granting exclusive rights, it is important for the licensor to spell out any limitations and restrictions the licensor may want to impose on the scope of the grant. Typically, the academic licensor will carve out certain elements from the rights it grants to an industry partner. Such carve-outs are often required to allow the institution to satisfy its obligations to the government and funding agencies under Bayh-Dole and also under the terms of many federal grants. As an example, the National Institutes of Health (NIH) has issued formal guidelines to ensure that institutions receiving NIH funding adopt reasonable terms and conditions in their agreements to ensure access and dissemination of research tools made in the course of that research (Federal Register 1999). And, more generally, a number of institutions have endorsed guidelines to help ensure that academic institutions in licensing their technology adhere to their core mission (AUTM 2007).

In a typical case, the licensor reserves the right for itself, and often other nonprofits, to use the licensed technology and related IP rights for noncommercial research. Usually, the carveout must be broad enough to ensure that the university will not be precluded from continuing research on any exclusively licensed product or method. Sometimes the university may seek a broader carve-out, for example, allowing the university to use the IP it has licensed in connection with research that is sponsored by other companies. Such reserved rights may be appropriate or even necessary, for example, when the exclusive license might cover use of fundamental research tools or enabling technology that other investigators at the university would likely use. The university, however, must keep in mind that the broader the exception to the exclusive license, the more difficult it will be to negotiate a commercially acceptable position.

Another typical carve-out relates to "prospective" rights, that is, rights to future technology, improvements, and inventions that have not yet been made. This situation arises most in collaborations involving very early-stage pro- jects (e.g., at target discovery), in which the company licensee seeks broad rights, including commercialization and exclusive rights to any inventions or technologies arising from the project. Such future IP may not necessarily even be directed to the specific goals of the collaboration. Tying up commercialization rights to future IP through a broad exclusive license to one company may unduly restrict the ability of other investigators not involved in the deal to engage in their own collaborations, even in different fields. Furthermore, the academic licensor may not be willing to take the risk of giving up future opportunities that may depend on such IP and may be more suitable to pursue with another party.

A common framework for allocating prospective rights has both parties obtaining nonexclusive rights to any newly developed IP for any of their internal R\&D work. Broader rights to future developed IP, such as commercial rights to sell or market products, or exclusivity in some or all fields of use may then be handled through several approaches. Such approaches often involve the grant of option rights to the company partner, for example, an option to negotiate in good faith for an exclusive license under commercially reasonable terms when such new IP or technology comes into being. Alternatively, for a collaboration directed to a very early-stage project, the company may be content with merely having access to the technology for its own R\&D. It can then address the terms for any commercial development only if it chooses to extend the relationship with a new deal.

Conceptually, these reservations first facilitate the mission of nonprofit research institutions by ensuring that the institution will maintain freedom to conduct basic research. Second, these reservations acknowledge the principle that to appropriately balance the competing interests of the licensor and licensee, the scope of rights that are licensed should reflect the scope of the deal, as well the stage of development of the licensed technology.

For the university, careful consideration should be given to how any grant of exclusive or proprietary rights or obligation of confidentiality might potentially affect its ability to pub- 
lish or present the research done under an industry collaboration. Such considerations include any provisions that may require a delay of publication or prior approval to publish results beyond customary academic practice. Commonly, the interest of the industry partner in protecting IP generated during the course of a collaboration may be accommodated by the right to review, remove proprietary information from, and request a reasonable delay (ordinarily no longer than $90 \mathrm{~d}$ ) of any proposed presentation or publication for purposes of patent filing. To this end, it is important to consider the interplay between various provisions in the agreement, which in practice may unduly restrict publication rights. For example, the agreement might provide the industry partner with a 6 -mo option to negotiate for an exclusive license on any new inventions. Such option rights, however, may have the practical effect of delaying publication if the agreement also restricts the university from undertaking any activity during the option period that could affect the scope of what it could license, for example, by publishing its research before a patent application has been filed.

\section{VALUATION AND PAYMENT STRUCTURES}

Payment structures and amounts flowing from a license relationship are crucial not only to negotiating and executing the deal, but ultimately also to the long-term success or failure of the relationship. A successful deal requires balancing the competing need of the academic licensor to obtain a fair return on its $R \& D$ investment with the company licensee's goal to make a fair profit in the face of multiple regulatory, legal, and commercial risks. The possible forms of payment rely on many factors. Common payment structures include, either alone or in combination with one another, upfront fees, royalties (e.g., on a fixed per-unit basis or as a percentage of sales), and milestone payments linked to specific performance events. Less common structures include one-time payments or annual fixed fees, typically because they are not sufficiently robust to bridge the expectation gap between the academic licensor and company licensee. Additionally, in some cases in which the company licensee owns or controls IP rights that may be of interest to the university, an alternative method of payment could include a cross license with the university. Part of the consideration for the deal might then include a license from the company for use of the relevant IP. Table 3 provides a general overview of common payment forms.

\section{Upfront Fees}

The academic licensor may ask for a lump sum upfront payment either to recover costs for past research or to fund its participation in the collaboration. Such costs commonly include research costs and the cost of applying for and prosecuting IP rights. Where a company licensee is an early-stage startup with little cash, an academic licensor may be willing to accept stock or other forms of equity as payment (thus making the academic institution a shareholder in addition to being a licensor). In some cases, for example, in which upfront fees are paid to cover future development costs, it might make sense for the license agreement to provide that some or all of the payment will be used to offset future royalties. Less commonly, an agreement may require full payment up front. Such an approach, however, is generally not suitable for biotechnology transactions where, for numerous reasons, the ultimate commercial value of any potential product may be difficult or impossible to measure. Such uncertainties can include whether the product will perform in human clinical trials as expected based on animal models, whether the product will receive regulatory approval, what price the market will sustain, risk of competitive alternatives, acceptance by healthcare professionals and/or patients, and potential need and cost for licenses from third parties to make and sell the product.

\section{Royalties}

Biotech licenses generally include royalty payments. As a primary consideration, the agreement should provide a clear definition of what licensed products and services are royalty bearing. The university licensor should bear in mind 
Biotech IP in University-Industry Partnerships

Table 3. Principal forms of license consideration

\begin{tabular}{|c|c|c|c|}
\hline & Description & Risks & Reducing risks \\
\hline Upfront fee & $\begin{array}{l}\text { Cash } \\
\text { Equity/stock (e.g., early- } \\
\text { stage startups) }\end{array}$ & $\begin{array}{l}\text { Uncertainty in future } \\
\text { commercial value }\end{array}$ & $\begin{array}{l}\text { Limit to sunk costs for R\&D } \\
\text { and IP } \\
\text { Credit against future royalties }\end{array}$ \\
\hline Milestones & $\begin{array}{l}\text { Defined payments linked to } \\
\text { specific performance events } \\
\text { Food and Drug } \\
\text { Administration approval, } \\
\text { achieving financing, etc. }\end{array}$ & $\begin{array}{l}\text { Unclear description } \\
\text { of performance events }\end{array}$ & $\begin{array}{l}\text { Clearly defined triggers: } \\
\text { actors, events, and timing }\end{array}$ \\
\hline Royalty & $\begin{array}{l}\text { Percentage of sales or profits } \\
\text { Per-unit basis } \\
\text { Payment term linked to life } \\
\quad \text { of the patents }\end{array}$ & $\begin{array}{l}\text { Licensee fails to } \\
\text { commercialize } \\
\text { Net sales-loss leaders and } \\
\text { free samples } \\
\text { Growth opportunities not } \\
\text { addressed }\end{array}$ & $\begin{array}{l}\text { Minimum royalty } \\
\text { Conversion of exclusive to } \\
\text { nonexclusive } \\
\text { "Commercially reasonable } \\
\text { efforts" with termination } \\
\text { right } \\
\text { Royalty covers new products, } \\
\text { acquisitions, and } \\
\text { sublicensed products }\end{array}$ \\
\hline
\end{tabular}

that the products and services sold under its license may change over time. The company licensee may, for example, look for opportunities to launch new or improved products or expand use of the products into new indications. Ambiguity in what is defined as a royalty-bearing product or service will likely give rise to later disputes about whether certain sales are covered under the license.

When setting a royalty rate, many factors come into consideration. A key consideration is the strength of protection offered by the licensed IP (e.g., patent validity, ease and cost of designing around, scope and restrictions of the license grant, remaining life of the licensed patents, or likelihood of infringing other nonlicensed patents owned by third parties). Key commercial factors include the potential size of the market; whether there is an established market price for the technology; the commercial relationship between the parties (e.g., whether the institution has other deals with the company); whether the technology is a research tool, compound, or diagnostic; and the extent of existing competing technologies in the market or the likelihood of market penetration.
Depending on these factors, it is often appropriate to set different royalty rates for different products and services that come under the license.

Royalties can be calculated as a percentage of sales or on a per-unit basis. Percentage of net sales is most common, and allows the royalty amount to automatically increase with increases in price. When royalties are based on net sales, a clear definition of how net sales will be calculated is essential to avoid future royalty disputes. For example, the company may market the product sold under the license as a loss leader or give away a meaningful fraction of the product for free. Such actions will erode the base against which the royalty is calculated unless the agreement incorporates some adjustment for belowmarket sales. In contrast, when calculated on a per-unit basis, the company licensee assumes the risk that if competition results in lower product price, it will be stuck paying the same royalty.

Payment of royalties rests on the assumption that the licensee will work diligently to commercialize the licensed product. To develop a biotech product for commercialization, how- 
ever, requires a long time. During that time, the company licensee's interests (or the market generally) may change so that it is no longer in the company's best interest to invest further in commercializing or marketing the licensed product. For example, the company can instead decide to develop (or in-license/acquire from a third party) a competing technology that is not covered by the academic license or to change its business to a new sector entirely. But when that happens, the expectation the academic licensor had in going into the deal does not materialize, especially if the university decided to trade upfront fees for a higher royalty rate.

To reduce this risk, particularly in the case of technologies that require significant further development before they achieve regulatory approval and commercialization, an academic licensor may wish to consider imposing a minimum royalty obligation. Thus, the academic licensor continues to receive payments in return for forgoing higher upfront fees or the opportunity to license the technology to another party. Properly structured diligence provisions, such as minimum royalties, can encourage the company licensee to either continue commercializing a licensed technology or instead release the technology back to the university.

This diligence provision can be structured to take into account other uncertainties the parties may have in going into a deal. For example, it may be difficult to know the appropriate minimal royalty before any commercial activity has begun. To account for this, it is common to include an adjustment mechanism once payments have started flowing and a market becomes established and understood. As another example, a product may not come to market for several years, leaving a small company without enough cash flow to meet its obligations. To account for this, the agreement can provide that if the minimum is not met, to retain its rights the company licensee can pay the difference, terminate the license, or short of that, convert an exclusive license to nonexclusive. These options give the academic licensor a new opportunity to pursue the technology with a different unrelated party. However, taking advantage of these options may be difficult if the university has lost several years of development time or, in the last case, the new partner wants exclusivity.

\section{Milestones}

Milestone payments based on performance provide a reasonable tool for bridging the valuation expectations gap between a licensee (who assumes that the technology will be successful and will fill the market need) and a licensor (who bears the risk of product failure at multiple junctures). Although milestone payments can be triggered by any kind of performance event, they are best suited for events that can be described with particularity. Ideally, milestones should be triggered by events that reduce future risk to the company licensee, in that by doing so, such events increase the value of the license agreement to the company.

Common milestones include first commercial shipment or sale of the licensed product, final Food and Drug Administration approval of an identified Biologics License Application, closing of a financing transaction raising a specified amount of funds, and achieving specified sales targets during a defined period or by a certain date. Performance milestones are those that can be satisfied with a reasonably predictable level of commercial diligence and are described so that both parties know and understand without ambiguity by whom the milestone was achieved, and on what day.

Ambiguous milestones can create fertile ground for disagreement leading to protracted and mission-distracting discussions and can irreparably damage an otherwise productive relationship. Care should be taken in describing the consequences of failing to achieve performance milestones. The academic licensor is likely to benefit from the right to terminate an agreement in which the company licensee failed to meet certain milestones, but termination need not be the first option. The company may be given a period to cure its failure, or the agreement can provide for dispute resolution procedures giving parties a mechanism for resolving disputes before having to trigger termination rights. 


\section{Further Considerations}

An academic licensor should be aware of potential lost opportunities for licensing revenues, particularly with respect to sublicenses granted by the company licensee to its third-party contract partners. Except where a company licensee is a large, fully integrated pharmaceutical company, a company licensee will very likely need to partner with other third parties to take a product through clinical trials to market. To do so, it will need the ability to grant sublicenses to select third parties. As a basic point, the agreement should ensure that the university receives royalties on third-party sales by sublicensees. The academic licensor should also take care to ensure that the agreement provides it with an appropriate share of the compensation the company receives for granting any sublicense.

Even when the payment structure and obligations are sufficiently understood and described in the license agreement, disputes may still arise about payments if the agreement fails to adequately describe the rights and obligations regarding record keeping and audits. License agreements therefore commonly include a requirement to keep complete and accurate books and records to verify royalties and other payments, both during the term of agreement and for a reasonable period thereafter. The obligation is typically backed up with a penalty or interest payment obligation for failure to accurately report. Such obligations become increasingly important as the likelihood that the market for the licensed product will change or grow (e.g., through sublicenses or new or acquired products).

Finally, it should be kept in mind that the license deal should be both well documented and commercially reasonable. The company licensee (especially startups) will likely need to obtain financing at some point in its life before products are approved and commercialized, either from a venture capital firm or other financial investor, from the equity capital markets through an initial public offering or follow-on offering, or in connection with acting as a takeover target during a merger and acquisition deal. If the license deal has unduly burdensome terms including unreasonable payment terms, the licensee could have difficulty executing any of these kinds of transactions (i.e., the license is "unbankable"), decreasing the chance that any licensed product will be an attractive investment target that will likely achieve successful commercialization.

\section{ENFORCEMENT AND REMEDIES}

Licensed patent rights occupy a central role in the value and structure of a license arrangement, whether simple or complex. Prosecution of the licensed patent claims (i.e., the process of drafting and filing claims and interacting with the patent office) involves precise technical thinking and drafting, and it is crucial that prosecution be addressed with care and diligence. Although it is common that the academic licensor retains control over prosecution activities given its vested interest in protecting its rights, an exclusive licensee also has a substantial financial interest in the scope of rights sought and obtained - and may also be responsible for paying at least some portion of the costs required for patent prosecution and maintenance. Company licensees will generally at least want to review and comment on communications with the patent office that impact the scope of the claims. Hence, an exclusive licensee normally demands at least some say-if not full control or veto rights - in how and where the patent rights are sought.

As with prosecution, defense of the licensed patents is also of considerable interest to exclusive licensees and can be the subject of extensive negotiation. In many instances, neither party is willing to cede control of litigation outright. In such cases, one party may retain control over the defense, but the other party is given the opportunity to review all material correspondence and documents and to provide some nonbinding input into decisions. In some cases, the controlling party may wish to decline enforcing the patent rights against third-party infringers. In that event, the other party might be given the option to step in at its own expense to enforce the patent rights with whatever cooperation it needs from its partner. In this regard, consider- 
V. Drozdoff and D. Fairbairn

ation should be given to the input each party will have in settling allegations of infringement with third parties and how to allocate costs and any amounts awarded by a court.

\section{CONCLUSION}

With the large number of blockbuster pharmaceutical products going off-patent in recent years (Cressey 2012), dwindling pipelines for new products, and pharmaceutical companies shedding or significantly reducing their R\&D programs, universities and other nonprofit academic institutions present an important source of new molecular targets and technologies for development and commercialization by life sciences companies. A successful licensing arrangement between an academic institution and a company benefits both partners, creates new products, and brings new diagnostic and treatment tools into the clinic. By understanding the unique issues that arise in structuring and negotiating license arrangements between academic institutions and companies, it is possible to increase the likelihood of a successful and productive relationship, and thereby achieve the promise of the Bayh-Dole Act.

\section{REFERENCES}

AUTM. 2012. U.S. licensing activity survey: FY 2012. Association of University Technology Managers, Deerfield, IL.
http://www.autm.net/FY2012_Licensing_Activity_Survey/ 11449.htm.

AUTM. 2007. In the public interest: Nine points to consider in licensing university technology. Association of University Technology Managers, Deerfield, IL. http://www.autm .net/Nine_Points_to_Consider1.htm.

Boettinger S, Bennett A. 2006. Bayh-Dole: If we knew then what we know now. Nat Biotechnol 24: 320-323.

Brody H. 2001. TR University Scorecard. MIT Technology Review, Cambridge, MA. September 1, 2001. http:// www.technologyreview.com/featuredstory/401184/truniversity-research-scorecard.

Cressey D. 2012. Big pharma approaching bottom of patent cliff. Nature news blog. October 12, 2012. http://blogs .nature.com/news/2012/10/big-pharma-approachingbottom-of-patent-cliff.html.

Edwards M, Murray F, Yu R. 2003. Value creation and sharing among universities, biotechnology and pharma. Nat Biotechnol 21: 618-624.

Federal Register. 1999. Principles and guidelines for recipients of NIH research grants and contracts on obtaining and disseminating biomedical research resources. Fed Regist 64: 72090-72096.

Feldman MP, Colaianni A, Liu CK. 2007. Lessons from the commercialization of the Cohen-Boyer patents: The Stanford University Licensing Program. In Intellectual property management in health and agricultural innovation: A handbook of best practices (ed. Krattiger A, et al.). MIHR, Oxford. http://www.iphandbook.org/hand book/chPDFs/ch17/ipHandbook-Ch\%2017\%2022\%20 Feldman-Colaianni0Liu\%20Cohen-Boyer\%20Patents\% 20and\%20Licenses.pdf.

Rai A, Sampat B. 2012. Accountability in patenting of federally funded research. Nat Biotechnol 30: 953-956.

Schacht WH. 2012. The Bayh-Dole Act: Selected issues in patent policy and the commercialization of technology. Congressional Research Service. http://www.fas.org/ sgp/crs/misc/RL32076.pdf.

Schachter B. 2012. Partnering with the professor. Nat Biotechnol 30: 944-952. 


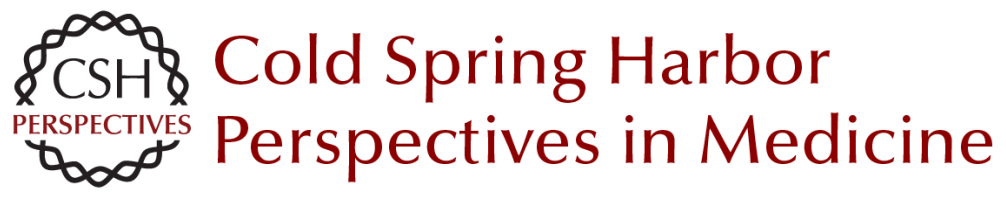

\title{
Licensing Biotech Intellectual Property in University-Industry Partnerships
}

\author{
Vladimir Drozdoff and Daryl Fairbairn
}

Cold Spring Harb Perspect Med 2015; doi: 10.1101/cshperspect.a021014 originally published online January 20, 2015

\section{Subject Collection Intellectual Property in Molecular Medicine}

Patentability of Stem Cells in the United States Sarah E. Fendrick and Donald L. Zuhn, Jr.

Inventorship and Authorship

Antoinette F. Konski and Linda X. Wu

The Patentability of Stem Cells in Australia Jenny Petering and Prue Cowin

Impact of America Invents Act on Biotech

Intellectual Property

Amanda Murphy, Michael Stramiello, Jonathan Stroud, et al.

Introduction to Intellectual Property: A U.S.

Perspective Amanda Murphy, Michael Stramiello, Stacy Lewis, et al.

The Role of Regulatory Agencies and Intellectual Property: Part I Kevin E. Noonan

Canada's Patented Medicines (Notice of Compliance) Proceedings and Intellectual Property Henry Bian and Conor McCourt

Patentability of Genes: A European Union Perspective Paul Cole
The Impact of Myriad on the Future Development and Commercialization of DNA-Based Therapies and Diagnostics

Michele Wales and Eddie Cartier

Protecting Traditional Knowledge Related to

Biological Resources: Is Scientific Research

Going to Become More Bureaucratized?

Prashant Reddy and Malathi Lakshmikumaran

Protecting Trade Secrets in Canada Noel Courage and Janice Calzavara

Inherent Anticipation in the Pharmaceutical and

Biotechnology Industries

Michael Goldman, Georgia Evans and Andrew Zappia

The Role of Regulatory Agencies and Intellectual

Property: Part II Kevin E. Noonan

Baseball Bats and Chocolate Chip Cookies: The Judicial Treatment of DNA in the Myriad Genetics Litigation lan Binnie and Vanessa Park-Thompson

The Impact of Myriad and Mayo: Will

Advancements in the Biological Sciences Be

Spurred or Disincentivized? (Or Was Biotech

Patenting Not Complicated Enough?) Jennifer Gordon

Trade Secrets in Life Science and Pharmaceutical Companies

Tara Nealey, Ronald M. Daignault and Yu Cai

For additional articles in this collection, see http://perspectivesinmedicine.cshlp.org/cgi/collection/ 